\title{
Rethinking the Relationship between Women, Crime and Economic Factors: The Case-Study of Women Sentenced to Death for Drug Trafficking in Malaysia
}

\author{
Lucy Harry
}

\author{
Centre for Criminology, University of Oxford, Oxford OX1 3UL, UK; lucy.harry@balliol.ox.ac.uk
}

check for

updates

Citation: Harry, Lucy. 2021. Rethinking the Relationship between Women, Crime and Economic Factors: The Case-Study of Women Sentenced to Death for Drug Trafficking in Malaysia. Laws 10: 9. https://doi. org/10.3390/laws10010009

Received: 23 December 2020

Accepted: 28 January 2021

Published: 31 January 2021

Publisher's Note: MDPI stays neutral with regard to jurisdictional claims in published maps and institutional affiliations.

Copyright: (๑) 2021 by the author. Licensee MDPI, Basel, Switzerland. This article is an open access article distributed under the terms and conditions of the Creative Commons Attribution (CC BY) license (https:// creativecommons.org/licenses/by/ $4.0 /)$.

\begin{abstract}
This paper draws upon my doctoral research into the experiences of women who have been sentenced to death for drug trafficking in Malaysia. I utilise this case-study as a lens through which to examine the relationship between women, crime and economic factors. From my data derived from 47 'elite' interviews, as well as legal and media database searches (resulting in information on 146 cases), I argue that current feminist criminological theorising should be updated to incorporate the relationship between women's crime and precarious work. As I show, precarity is gendered and disproportionately affects women from the global south. Overall, I find that many of the women who have been sentenced to death in Malaysia were engaged in precarious work and drug trafficking was a way to make 'quick money' to address economic insecurity. Clearly, capital punishment is incommensurate with the crime.
\end{abstract}

Keywords: gender; death penalty; drug trafficking; southern criminology

\section{Introduction}

On 10 October 2018, on World Day Against the Death Penalty, the United Nations (UN) called for the introduction of a gender-based approach towards the death penalty (Callamard 2018). Since then, this largely invisible death row population has begun to receive much-needed attention. Most notably, Cornell Law School's report, Judged for More Than Her Crime: A Global Overview of Women Facing the Death Penalty, found that the population of approximately 500 women who face the death penalty worldwide are victims of gender-based discrimination and have faced, and continue to face, various forms of oppression (Cornell Center on the Death Penalty Worldwide 2018). Up until this point, very few references had been made to women facing capital punishment, and those few had focused upon women sentenced for homicide in the United States (US), arguing that women benefit from a gender bias at sentencing which has meant they are often spared the ultimate punishment (Streib 1990, 1992, 2002, 2005, 2006; Carroll 1996; Shapiro 2000; Shatz and Shatz 2012). Such analyses fall short in their comprehension of the unique and often-times disadvantaged circumstances that give rise to female criminality.

This article is based upon the findings of my doctoral research into the pathways to offending of women sentenced to death for drug trafficking in Malaysia. Over $90 \%$ of the world's executions occur in Asia, yet this continent has received the least academic attention as compared to other capital punishment regimes (Johnson and Zimring 2006, p. 91). In Malaysia, there are far fewer women on death row than men (141 as compared to 1140) (Amnesty International 2019). But, crucially, there is a higher proportion of women $(95 \%)$ on death row for drug trafficking compared to the proportion of men on death row for the same offence (70\%) (Amnesty International 2019, pp. 18-20). Additionally, a far higher percentage of the female death row population are foreign nationals $(86 \%)$ as compared to the percentage of foreign nationals on the male death row (39\%) (Amnesty International 2019, p. 19). Therefore, I examine these differences by focusing on the drivers behind women's engagement in international drug trafficking in Southeast Asia. Furthermore, it is 
important to note that drug offences do not meet the threshold of 'most serious offence' as stipulated by Article 6 (2) of the International Covenant on Civil and Political Rights, and therefore should not warrant the death penalty.

The little evidence that has emerged regarding women on death row in Southeast Asia suggests that many of the women who are facing the death penalty for drug offences are 'foreign, from poor countries; many are mules' and likely became involved in crime as a consequence of 'gender disempowerment' and marginalisation (Fleetwood and Seal 2017, p. 364; Cornell Center on the Death Penalty Worldwide 2018, p. 12). So far, much of the information about this population has been anecdotal. Through my empirical research I aim to substantiate these claims with the numbers, socio-economic profiles, and circumstances of cases involving women sentenced to death for drug trafficking in this jurisdiction. I am concerned with why and how women become involved in drug trafficking in Southeast Asia. To answer these questions, I rely upon interviews with a variety of stakeholders in Kuala Lumpur, Malaysia, including lawyers, judges, prosecutors, police, NGO activists, academic researchers, journalists and consular officials. And, to triangulate my findings, I additionally conducted extensive searches of both legal and media databases.

In this article, I focus on one particular issue that arose from my data collection. When reflecting upon why women become involved in drug trafficking that leads to the death penalty in Malaysia, participants consistently cited economic factors. However, it became apparent that here was a nuanced story that is not adequately explained by prior theorising on the feminisation of poverty thesis. While occasionally abject poverty will lead to women's involvement in crime, in many cases, it seemed that economic precarityexacerbated by the global forces of neoliberalism and post-colonialism-was a greater driver. Prior studies have shown that women make up a disproportionate portion of the world's precarious workforce, especially in the global south, in part due to the burden of care and gendered division of labour (Fudge and Owens 2006; Standing 2011). My findings show that many of the women facing the death penalty in Malaysia were either unemployed, or employed in low-level, low-paid, precarious work. According to my interview participants, due to a situation of economic insecurity, women may engage in drug trafficking as a way to make 'quick money' to serve an immediate financial need. Therefore, in this article I build upon existing criminological theorising on women, crime and economic factors, and utilise this Malaysian case study to enrich our understandings of this relationship in a southern, postcolonial context.

\section{Literature Review}

There has been a consideration of the relationship between women, crime and economic factors since the inception of the feminist turn in criminology. Indeed, Klein's (1973) The Etiology of Female Crime discusses 'obviously economically motivated offenses, such as prostitution and shoplifting' (p. 6; my emphasis). During the same decade, the concept of 'the feminisation of poverty' was rising in prominence. This term was coined by Pearce (1978), a US sociologist, who argued that in the latter part of the 20th century, women were disproportionately affected by poverty. This trend emerged alongside neoliberal reforms and a reduction in the welfare state. Simultaneously, we see in sociology and criminology an increased concern with the overlap between penal and welfare institutions. In Wacquant's (1999) classic text, Prisons of Poverty, he argues that 'the invisible hand of the market necessitates and calls forth the iron fist of the penal state'. This so-called 'war on the poor' is referred to by some as a 'war on women' as the effects of these policy reforms are felt most acutely by women (Davis 1991). Indeed, in Carlen's (1988) seminal text, Women, Crime and Poverty, she argues that women's law-breaking is closely related to their patterns of social control, against the backdrop of Thatcherism and the 'New Right' political economy. Indeed, for the 39 'criminal' women she interviewed, she found that poverty was a key feature in all of their lives, and additionally found that they were exploited by both the 'class deal' and the 'gender deal' causing them to commit crime when they were unable to reap the 'imaginary rewards of respectable working-class womanhood' (Carlen 1988, p. 13). 
Moreover, working-class women's dependence on welfare is demonised and criminalised, and we see a rise in popular discourse of the 'welfare queen' or 'welfare fraud' folk devil (Chunn and Gavigan 2004; McCorkel 2004; Gelsthorpe 2010).

Elsewhere, we see criminological studies examining the relationship between women, crime and economic factors that move beyond the neoliberal agenda. Some studies focus on the specific types of economic crimes that women commit, for example, robbery (Miller 1998); prostitution (Phoenix 1999); and white collar crime (Daly 1989). Here we see a tension between women committing crimes for 'need' versus 'greed' (Davies 2003a, p. 292). Other commentators examine socioeconomic factors as 'vulnerabilities' contributing towards women offending (Corston 2007). Or, in the 'feminist pathways to crime' literature, we see poverty as a 'risk factor' for offending (cf. Daly 1992; Richie 1996). More recently, class and economic factors are considered in consortium with other axes of disadvantage-such as gender, race and sexuality-with the dawn of intersectional approaches to criminology (Potter 2015). Pertinently, the debate around the relationship between women, crime and economic factors provides rich theoretical ground upon which to examine the tension between women's agency and broader structural factors when it comes to offending. We see this most clearly in the work of Maher (1997), who conducted an ethnography of women drug users engaging in the street-level drug economy in New York City, and called for a greater appreciation of 'the relationships between broader social, economic, and cultural formations and immediate, specific, and local contexts in structuring the conditions by which women's agency is enacted' (p. 1).

Although it is somewhat outdated, in Davies' (2003b) paper she calls for feminist criminologists to consider the relationship between women, crime and work:

[T] here are invisible female offenders whose 'grafting' and crimes may indeed represent work-the professional shoplifter or specialist purse-pincher, the kite, the drug dealer and the prostitute ... There are also women, who, having a legitimate job, also have the additional opportunities to do their crime at workwhite-collar thefts or embezzlement and fraud. (p. 19)

This nexus between women, crime and work is of particular relevance to this paper's case-study, as we explore the motivations of women who have become involved in drug trafficking, in many cases for economic gain. Accordingly, we can turn to a corresponding body of criminological literature that considers women's motivations for smuggling drugs, the majority of which focus upon women from Latin America, the Caribbean and West Africa, smuggling to the US or the UK (Del Olmo 1986; Huling 1995, 1996; Green 1996; Heaven 1996; Esmee Fairbairn Foundation 2003; Sudbury 2005; Torres 2008; Office of the Sentencing Council 2011; Bailey 2013; Fleetwood 2014; Constant 2017); with the notable exception of studies of women incarcerated for drug trafficking in Thailand (Jeffries and Chuenurah 2019).

It is significant that, in all of these papers, the authors offer some form of economic explanation (alongside other factors) for why women become involved in drug trafficking. Indeed, the first academic reference to female drug traffickers, from Del Olmo (1986), argues that with the economic crises and rising unemployment in Latin America, women engage in the illicit drug market as a viable form of subsistence (p. 167). Much more recently, Fleetwood's (2014) work on women sentenced for trafficking cocaine in Ecuador utilises the concept of 'provisioning' to portray how some women may engage in drug smuggling in order to 'meet the demands of parenthood' (p. 98). Elsewhere, Sudbury (2005) invokes the 'feminisation of poverty' thesis, and argues that as a consequence of the International Monetary Fund (IMF) restructuring of Caribbean economies, there has been a reduction in public sector jobs-usually held by women - and a cut in welfare and social benefits, as well as an increase in the cost of living, which disproportionately affects women who traditionally assume domestic roles in Caribbean families (p. 173). Nevertheless, there are examples in the literature in which women's engagement in drug trafficking is not borne out of desperate circumstances, but in fact from a desire to travel and profit from the financial reward (Bailey 2013; Fleetwood 2014; Jeffries and Chuenurah 2019). Clearly, 
there is a continuum of economic motivations, some of which may be shared by male drug traffickers.

In this current paper, I propose an alternative conceptualisation of the relationship between women, crime and economic factors and/or work. I argue that women's engagement in drug trafficking in Southeast Asia should be conceptualised in relation to their positions as precarious workers in the global labour market. In a situation of persistent financial and employment insecurity, drug smuggling for money becomes another form of precarious work. Here, economic insecurity is a greater driver than abject poverty. Accordingly, we can turn to a body of literature on the precarious nature of labour relations (cf. Neilson and Rossiter 2008; Standing 2011). This scholarship argues that since the 1980s and the dawn of neoliberalism, there has been a shift in the structure of the global labour market, from a model that privileged long-term, stable jobs and social benefits towards an increasingly networked, flexible and insecure labour market, accompanied by a decline in the welfare state (Han 2018, p. 335). This new model of precarious labour is, in fact, gendered (Fudge and Owens 2006). Women occupy a disproportionate number of short-term contracts or worse yet, are working without a contract at all (Standing 2011, pp. 60-61). Often these positions are part-time or on a temporary basis, and offer little opportunity for career progression (Standing 2011, p. 61). On top of this, women may be burdened with caring for family members without the assistance of social benefits ( Standing 2011, p. 61). While there is an increasing share of women in the global workforce, this may not be particularly empowering for those (without the benefits of class status or education) who find themselves 'labouring repetitively on an assembly line, or sewing feverishly in an ill-lit backstreet garment factory, or sitting at a check-out counter for long shifts' (Standing 2011, p. 61).

Women in the global south are most acutely affected by precarity (Standing 1989). We see this in the Southeast Asian region, both historically and presently. During the economic growth and structural adjustment processes that occurred from the 1960s to the 1980s in the ASEAN region, there was an unprecedented increase in women's participation in the labour market (Lim 1993). However, this was disproportionately in low-wage, manufacturing jobs in industrial export zones, where in some places, women made up more than $80 \%$ of the workforce (Lim 1993, p. 176). It was seen as economically advantageous to employ women in these roles, as often this was their first entry into the labour market and so they had low 'aspiration wages', and the women would be retrenched once they reached the age of marriage or childbirth, to be replaced by a more 'youthful' and 'productive' workforce (Standing 1989, p. 1080). This strategy was underpinned by orientalist discourses where:

Women are considered not only to have naturally nimble fingers, but also to be naturally more docile and willing to accept tough work discipline, and naturally less inclined to join trade unions, than men; and to be naturally more suited to tedious, repetitious, monotonous work. (Elson and Pearson 1981, p. 93)

Indeed, with regard to the case-study at hand, a variety of authors have shown how Malaysia's post-independence economic development in the latter part of the 20th century occurred largely off the backs of women in the manufacturing sector (Elias 2006; Kaur 2000). However, it would be erroneous to consider this female workforce as wholly passive, as Ong's (1987) Spirits of Resistance and Capitalist Discipline makes clear; this ethnography of factory women in Malaysia highlights the everyday acts of subversion and resistance to the capitalist modes of control. This brings us onto a more contemporary study of the labour force participation of working class women in Penang, Malaysia, where Franck (2016) shows that across the life course the women she interviewed move from formal employment in low-skilled jobs in global factories or in the tourism industry, to small-scale informal businesses (such as street hawking), as an agentic response to the constraints of the working conditions in the export industries (namely, the temporary and precarious nature of the employment; the long shifts and poor salaries; as well as the geographic distance from their homes to the export processing zones) (pp. 169-70). For many of the women, the decision to move from the formal economy to the informal economy was not 
borne out of desperation, but in fact was a 'deliberate choice' driven by a desire for more freedom and flexibility to enable them to balance their domestic roles within the family alongside their economic lives (Franck 2016, p. 174). This example also illustrates how precarity is endemic to both the formal and informal sectors of employment.

Elsewhere, we see that the majority of the work focusing on precarious employment in Malaysia is concerned with the plight of migrant workers, especially those working within the palm oil industry or as domestic workers (Pye et al. 2012; Kumar et al. 2014; Au et al. 2019; Miles et al. 2019). With regards to the former, Malaysia's palm oil sector is heavily reliant upon roughly 1 million migrant workers, the majority of whom are from neighbouring Indonesia (Pye et al. 2012, p. 330). Plantation workers-especially those employed by small holdings companies-are subjected to poor working and living conditions (Kumar et al. 2014). This type of employment is precarious by its very nature: the visa permit scheme for migrant workers precludes permanent employment (and is usually issued for three years); and the industry has a flexible design in order to respond to fluctuations in the global market, and thus workers lack employment security (Pye et al. 2012, pp. 331-33). Moreover, Oliver Pye and colleagues (Pye et al. 2012) argue that this situation of precarity extends outwards to encompass the migrant workers' political and social-psychological realms; by way of examples, migrant workers are heavily surveyed, controlled and suppressed by their employers and the state (political precarity); and they live in isolation from their familial support networks, and are in a constant state of insecurity due to threats of police raids and deportation (psycho-social precarity) (pp. 331-34). The plight of migrant domestic workers is not all that dissimilar. A key distinction is the fact that domestic work occurs within the privacy of the employer's home and thus is even harder to regulate, leaving domestic workers vulnerable to abuse. In Malaysia, there are approximately 300,000-400,000 migrant domestic workers (Harkins 2016; Miles et al. 2019). Research into their experiences has shown that these workers face intersecting forms of discrimination, by virtue of their gender, class status and foreign citizenship (Miles et al. 2019). We see these forces at play within the current case-study.

\section{The Case-Study}

In this study, I focus on the specific case of the Malaysian death penalty, with a particular focus on women sentenced to death for drug trafficking, to illustrate the broader issue of women, crime and economic factors. Capital punishment was introduced in Malaysia during British colonial rule, and has been retained since independence in 1957. Currently, nine laws and 33 offences carry the death sentence (12 of which, carry the mandatory death penalty) (Amnesty International 2019, p. 13). The contemporary use of the death penalty is mainly restricted to the crimes of murder, drug trafficking, and occasionally fire-arms related offences (Amnesty International 2019, p. 13). If charged with a capital offence at the Magistrates Court, the case will be sent to the High Court and from there the decision may be appealed to the Court of Appeal, followed by the Federal Court; finally, an application for pardon may be made to the ruler of the state or the King (Pascoe 2019). The death penalty for drug trafficking - the focus of this paper-is governed by the Dangerous Drugs Act of 1952, a law that was introduced by the British colonial government, but, pertinently, it did not carry the death sentence until 1975 (after independence), and it only became the mandatory sentence in 1983 as the government instituted its anti-drugs campaign (Harring 1991). Some reforms to the mandatory death sentence were instituted in 2017, however these were very limited in scope-a judge may exercise discretion if the accused person is said to have cooperated with law enforcement and consequently 'disrupted' wider drug trafficking operations-and thus it operates largely mandatorily in practice (Amnesty International 2019, p. 14). On 10 October 2018, World Day Against the Death Penalty, the then Malaysian Law Minister, Liew Vui Keong, announced the government's intention to abolish the death sentence; however-in part due to political upheavals- there has been little by way of progress since then (Antolak-Saper et al. 2020, p. 5). 
Attempts to study the Malaysian death penalty are routinely hampered by the lack of transparency when it comes to official statistics about the death row population and records of executions (Pascoe 2016). However, Amnesty International's (2019) report, Fatally flawed: Why Malaysia must abolish the death penalty, obtained official statistics which indicate that, as of February 2019, there are 1281 people-1140 men and 134 women-under sentence of death in Malaysia (p. 19). The majority of those on death row have been sentenced to death for drug trafficking: $73 \%$ of the men on death row, and an alarming $95 \%$ of women (Amnesty International 2019, p. 19). There is also a disproportionately high rate of foreign national women on death row (86\%) as compared to the male death row population (39\%) (Amnesty International 2019, pp. 19-20). With regards to executions, 469 executions have occurred since independence in 1957 (a significant proportion of which-229_for drug trafficking), albeit these statistics are not disaggregated by gender (Amnesty International 2019 , p. 15). Furthermore, Amnesty International has recorded 30 executions during the years 1998 to 2018, and the last known execution occurred in 2017 (4 persons were executed during this year) (Amnesty International 2019, p. 18; Cornell Center on the Death Penalty Worldwide 2018). The Amnesty International report also offered a rare insight into the socio-economic profiles of those on death row in Malaysia: '[a]ccording to official sources, 440 people, or $34 \%$ of all those on death row were classified as unemployed or not having a permanent job; a further 126, or 10\%, as "labourers"' (Amnesty International 2019, p. 22).

There are a number of other notable academic and civil society studies of the Malaysian death penalty (Hood 2013; Han et al. 2018; Hoyle 2019; Antolak-Saper et al. 2020). The 2013 public opinion report by Roger Hood, in conjunction with the Death Penalty Project, finds that of the 1535 Malaysian people sampled, the majority are in favour of the death penalty (mandatory or discretionary) and 74-80\% specifically support the death sentence for drug trafficking (Hood 2013). However, one of the survey questions involved the following hypothetical scenario:

A Malaysian woman, aged 21, was stopped by immigration at KL airport and when searched was found to have 100 grams of heroin hidden in a false bottom of her suitcase. She claimed that a foreign man she had met on holiday had asked her to carry the suitcase as a special favour. She had no previous criminal record. She was convicted of trafficking and sentenced to death. (Hood 2013, p. 13)

Pertinently, public support for the death penalty plummeted from $74 \%-80 \%$ to $9 \%$ when respondents were presented this case (Hood 2013, p. 13). Whilst this suggests that the public may be reluctant to see a woman sentenced to death in such cases, research findings from the Penang Institute show that women are less likely to be acquitted of drug trafficking cases in Malaysia as compared to their male counterparts (Han et al. 2018, p. 7). Moreover, other research addresses the vulnerability of certain capital defendants within the Malaysian criminal justice system, namely foreign nationals (Hoyle 2019; Antolak-Saper et al. 2020).

With regards to research on women imprisoned in Malaysia more generally-who currently make up $4.5 \%$ of the nation's carceral population-there are a few existing studies (World Prison Brief 2019). Of these, some have adopted a medical lens and have examined the high prevalence of psychiatric and psychological disorders amongst the female prison population of Malaysia (Zamzam and Hatta 2000; Mazlan and Ahmad 2012). Others have examined the socio-demographic factors and backgrounds of female offenders imprisoned in Malaysia (Teh 2006; Samuel and Omar 2012). The most detailed account comes from Teh (2006) whose study of 422 female prisoners in Malaysia finds that the majority of the inmates were engaged in criminality due to economic marginality: with $17 \%$ of the female prisoners being unemployed prior to incarceration, and of those who were employed, around half of them were living under the poverty line (p. 48). The research also finds that $52 \%$ of the female inmates are foreign nationals (mainly from neighbouring Indonesia and Thailand), and amongst the foreign national prisoners the most common offence type was an immigration offence, whereas for the Malaysian national prisoners the most common offence type was a drug offence (Teh 2006, pp. 48-51). Teh argues that her findings 
regarding the 'pathways to crime' of her participants are largely fitting with Western criminological theories on the matter, with many of the participants citing risk-factors such as physical abuse, sexual abuse, drug and alcohol abuse, and unstable familial situations (Teh 2006, p. 45; Daly 1992; Richie 1996; Chesney-Lind 1997; Belknap and Holsinger 2006). However, this study is limited in scope due to the fact that Teh was unable to interview the five women on death row at the time, owing to prison security regulations (Teh 2006, p. 47). Therefore, in this current paper, I intend to address the gap in knowledge regarding the female death row population, and delve deeper into the nuances of the 'economic marginality' argument.

\section{Methodology}

In this paper, I adopt a 'case-study approach' to the subject matter. This methodological approach is characterised as follows:

[A] qualitative approach in which the investigator explores a bounded system (a case) or multiple bounded systems (cases) over time, through detailed, indepth data collection involving multiple sources of information (e.g., observations, interviews, audiovisual material, and documents and reports), and reports a case description and case-based themes. (Creswell 2007, p. 73)

I additionally draw from the burgeoning literature on 'southern criminology' to develop my methodology. The mandate of this approach is 'to elucidate the power relations embedded in the hierarchical production of criminological knowledge that privileges theories, assumptions and methods based largely on empirical specificities of the global North', and in so doing, it aims to 'decolonize and democratize the toolbox of available criminological concepts, theories and methods' (Carrington et al. 2016, p. 1). Much of the inspiration for this approach is derived from the work of the Australian sociologist, Connell (2007) on 'Southern Theory'. Connell examines the global economy of knowledge production, and posits a division between what she terms the 'centre' and the 'periphery' (in essence, the Global North and the Global South). The former is where theories are developed, and the latter is regarded as a 'data mine' for the gathering and testing of said theories. It is argued that theories that are developed in the Global North are then imported to the periphery, where they are applied irrespective of the histories and experiences of those in the South. I attempt to address this issue within this paper, by testing the limits of existing theories of women, crime and economic factors and their applicability to the situation in the global south, and specifically women sentenced to death for drug trafficking in Malaysia.

With regards to the practicalities of my research, I am restricted somewhat by the relative opaqueness of official statistics on the death penalty in Malaysia. Indeed, Hood and Hoyle (2015) point out that Malaysia is one of the five most secretive retentionist states who do not publish official data on their death penalty practices as part of the United Nations Quinquennial Survey of member states (p. 174). Another researcher focusing on the death penalty in Southeast Asia, Pascoe (2016), offers methodological advice on how to overcome the challenges of accessing data, and suggests deploying a triangulating technique:

[d]eath penalty researchers can rely upon available official sources (such as government archives, press releases and reports, speeches and autobiographies), non-official sources (such as independent media reports and foreign and local NGO publications), together with 'elite' interviews. (p. 204)

Consequently, I draw upon a range of sources, including: local and international NGO reports; media articles; recorded judgments from the Malaysian High Court, Court of Appeal and Federal Courts; and 'elite' interviews. I conducted semi-structured interviews with 47 'elite' stakeholders, the range of whom is detailed in Table 1. The majority of these interviews were conducted face-to-face during my fieldwork in Kuala Lumpur, Malaysia. However, owing to the COVID-19 pandemic and ensuing lockdowns, several interviews were conducted virtually. After transcribing these interviews, I conducted a thematic 
analysis using a coding framework on the software NVivo. Owing to ethical and access issues, I did not attempt to interview any women on death row in Malaysia.

Table 1. Details of elite interviews.

\begin{tabular}{cc}
\hline Type of Elite Participant & Number Interviewed \\
\hline Academic researcher & 5 \\
Consular official & 2 \\
Journalist & 3 \\
Judge & 1 \\
NGO worker (international) & 9 \\
NGO worker (local) & 5 \\
Prosecutor & 1 \\
Lawyer & 17 \\
Police inspector & 1 \\
Religious counsellor & 3 \\
\hline
\end{tabular}

In order to systematically gather media articles and recorded legal judgments, I conducted extensive searches of both legal and media databases. I triangulated my findings across multiple databases to ensure that my findings were as comprehensive as possible. However, I was limited to English language resources. The legal databases I searched were: Lexis Nexis, WorldLii, SSC Online and LawCite. Details of the search terms I deployed (where a search term function was provided) are listed in Appendix A, Table A1; these search terms are broad as I found more specific searches did not yield any results, so I cast a wide net and manually reviewed and included or excluded files where appropriate. After reviewing my research results and deleting duplicates, I had files on a total of 127 women's cases, the relevant details of which will be provided in the next section. In terms of the inclusion/exclusion criteria, I only included cases where the accused person had been charged after the year 1983 (when the death penalty became mandatory in Malaysia) up until the present day (the most recent cases available include arrests in 2017). I also only included cases where the individual had received a death sentence (there were additional cases where a female suspect was charged under Section 39B of the Dangerous Drugs Act 1952 , but the charge was dropped prior to trial; or they were acquitted and discharged at trial; or their charge was reduced to one of 'possession' and thus they did not receive a death sentence). I included cases where the death sentence was later overturned on appeal, provided the individual had received a death sentence at some stage in the legal process.

Because in Malaysia it is not mandatory to record court judgments and make them publicly accessible, I am limited to the cases that judges have-for some reason or anotherdecided to document. In order to pick up on the cases that may have eluded the court record, I conducted a systematic research of the media databases, Factiva and Nexis UK. Again, this search was limited to English language sources. Tables A2 and A3 in Appendix A provide an overview of the search terms I utilised for each of these resources, which are tailored to the individual functionalities of the two databases. I then conducted a manual online search of popular English language news journals in Malaysia-New Straits Times, Malay Mail and The Star - as well as a more generic search of Google News. For these, I used a combination of the search terms detailed in Appendix A Table A4, as these online sources do not have more complex search functions. Utilising the same exclusion/inclusion criteria as I used for the legal database search, I was able to narrow down my findings to a total of 248 articles pertaining to 43 women's cases. Of these women's cases, I identified 24 that overlapped with the cases I found through my legal database search, and thus I identified 19 new cases that were not picked up in the legal database. This brings my total number of women's cases identified between both the legal and media databases search to 146 women's cases (see Appendix A, Table A5).

My study builds upon existing research on this area-namely recent reports from Amnesty International (2019) and Monash University (Antolak-Saper et al. 2020)_and offers some distinct contributions. Most notably, through my focus on women's pathways 
to crime, I have compiled more detailed evidence about the socioeconomic statuses and life histories of the women prior to death row. The Monash report provides details on the cases of five foreign national women who were sentenced to death for drug trafficking in Malaysia; albeit, the focus of the report is on the access to fair trials, and thus the information on the women's cases is provided only in relation to this concern (AntolakSaper et al. 2020, pp. 34-36). With regard to the Amnesty International (2019) report on the Malaysian death penalty, referenced afore, it provides critically useful information on the current numbers of women on death row; but the researchers only reviewed 30 cases of women on death row in Malaysia for drug trafficking, coming to the conclusion that these cases are characterised by 'coercion and deceit' (Amnesty International 2019, pp. 20-21). My research aims to increase the scope and depth of these analyses of the backgrounds of the women's cases. I include women's cases from the entire history of the mandatory death sentence for drug trafficking in Malaysia; indeed, the earliest case that I have information on involves a death sentence passed in 1987. Through my review of legal and media documents, I focus most heavily on sections detailing the 'defence' of the accused person (if indeed, this information is available). Consequently, I have extracted the following re-sults, listed in the Tables below. In the interest of anonymity, I have listed the different categories of information separately so that the women whose cases I have explored cannot be readily identified.

\section{Findings and Discussion}

In all of my interviews, participants cited an economic reason for why women engage in drug trafficking that leads to the death penalty in Malaysia. Time and time again I heard familiar phrases repeated to me: women carried drugs in order to make 'quick money', 'a quick buck', 'easy money' or 'fast money'. Often this was to supplement money coming in from other sources, so it was referred to as 'extra income' or 'extra money'. As we have seen above, other academic studies of women who engage in drug trafficking routinely cite economic factors as a major driver behind women's participation (Del Olmo 1986; Sudbury 2005; Bailey 2013; Fleetwood 2014). However, I wish to stress here that it was not necessarily a situation of abject poverty - explained by the feminisation of poverty thesis-that pushed women to engage in drug trafficking (knowingly or unknowingly). Indeed, one academic researcher told me that drug syndicates are unlikely to recruit someone in a dire situation, as 'you have to have your wits about you, you have to be presentable; there are a whole range of things that you need not alert the authorities to'. So, instead we see that many of the women on death row for drug trafficking in Malaysia were in fact employed at the time of arrest, but needed additional money in order to counterbalance the precarious nature of said employment.

Before delving into the evidence, it is important to highlight the significance of my proposed change of perspective from women engaging in drug trafficking due to the feminisation of poverty to an understanding that women tend to engage in drug trafficking due to economic precarity. This shift in viewpoint has real-life implications in the trials and appeals of women facing the death penalty in Malaysia. From reviewing the recorded judgments of 127 cases, it became clear to me that members of the judiciary have preconceptions about the 'typical' profile of a female drug mule. I repeatedly found that judges would comment on the socioeconomic backgrounds of accused persons and use this as an inference of guilt or intent. By way of examples ${ }^{1}$ :

The background of the accused revealed that she was quite capable of taking care of herself. She had a High School education, she understands and speaks simple English ... She had travelled extensively and also did modelling part-time; she was hardly a naïve or gullible person.

1 Due to ethical concerns about identification, I have not cited the cases these quotations come from. I have also edited the quotations to remove minor grammatical errors. 
Her handbag contained make-up, ladies' accessories, a Gucci watch, sunglasses and a wallet containing American Dollars ... These items are not a poor lady's possessions, but the items indicate she is a socialiser-a lady of the "world".

We are of the considered view that it is very unlikely that the respondent, who is a diploma holder ... could have placed herself in a situation where she could be exploited to commit a crime.

Additionally, when dismissing defences, judges made multiple references to accused persons not being 'uneducated', 'naïve', 'simpletons', and in one case, a judge pointed out that the accused woman came from a 'middle-class family'. It would seem that judges in these cases have a stereotype in mind of a vulnerable, uneducated dupe who may be more deserving of mercy. In fact, the situation is more complex, and as one of my participants stated, women on death row for drug trafficking in Malaysia are just 'everyday people in the gig economy'. Thus, my intention is to shed light on the unfavourable and gendered conditions of the precarious labour market and the implications this has had for women facing the death penalty in Malaysia.

Table 2 provides an overview of the stated occupations of women who were sentenced to death for drug trafficking in Malaysia between 1985 and 2019. Many of the women were engaged in low-paid, low-skilled jobs within the service sector. Some examples include: cashier, waitress, domestic worker, rubber tapper, water metre reader, bartender and courier. Aside from perhaps those who worked as teachers, a nurse and a freelance accountant, none of the other professions required higher education nor much training. Those working in sex work or in massage parlours will likely have been engaging in the illicit economy. A not insignificant number also cited that they ran small businesses or market stalls, and indeed Table 3 illustrates that many of women stated that their reason for travel was to procure cheap goods for their businesses. All of these jobs fit within definitions of precarious work, which are characterised by a lack of employment security and impossibility of 'upward social mobility' (Han 2018, p. 335). Moreover, we see that 13 of the women's cases reviewed cited no employment, and this fits with my findings from interviews which revealed that many of the women had 'no specific work' or did 'odd jobs' - again an indictment of a precarious labour market.

Table 2. Occupations of women sentenced to death for drug trafficking in Malaysia 1985-2019.

\begin{tabular}{|c|c|}
\hline Occupation & Frequency \\
\hline $\mathrm{N} / \mathrm{C}$ & 59 \\
\hline Unemployed & 13 \\
\hline Small business owner & 8 \\
\hline Domestic worker & 7 \\
\hline Courier for clothing company & 6 \\
\hline Masseuse & 5 \\
\hline Waitress & 5 \\
\hline Market trader & 4 \\
\hline Hairdresser & 4 \\
\hline Student & 3 \\
\hline Bartender & 3 \\
\hline Beautician & 3 \\
\hline Shop assistant & 2 \\
\hline Courier for import/export business & 2 \\
\hline Cashier & 2 \\
\hline Teacher & 2 \\
\hline Courier for IT company & 2 \\
\hline Cleaner & 2 \\
\hline Hotel staff & 1 \\
\hline Welfare volunteer & 1 \\
\hline Photographer & 1 \\
\hline Nurse & 1 \\
\hline
\end{tabular}


Table 2. Cont.

\begin{tabular}{cc}
\hline Occupation & Frequency \\
\hline Golf caddy & 1 \\
Chef & 1 \\
Freelance accountant & 1 \\
Housewife & 1 \\
Courier for medical supplies company & 1 \\
Water metre reader & 1 \\
Rubber tapper & 1 \\
Entertainment industry & 1 \\
Sex worker & 1 \\
Events planner & 1 \\
TOTAL & $\mathbf{1 4 6}$ \\
\hline
\end{tabular}

(N/C denotes 'not clear').

Table 3. Stated reasons for travel where women's cases involved international travel (N/C denotes 'not clear' and N/A denotes 'not applicable').

\begin{tabular}{|c|c|}
\hline Reason for Travel & Frequency \\
\hline Paid to courier items & 51 \\
\hline Clothing & 20 \\
\hline Medicine & 8 \\
\hline Electronics & 5 \\
\hline N/C & 5 \\
\hline Children's clothing & 3 \\
\hline Confidential documents & 2 \\
\hline Diamonds & 2 \\
\hline Bag & 1 \\
\hline Cosmetics & 1 \\
\hline Fitness equipment & 1 \\
\hline Metal & 1 \\
\hline Money and children's clothing & 1 \\
\hline Perfume, cigarettes and soap & 1 \\
\hline $\mathrm{N} / \mathrm{A}$ & 27 \\
\hline Asked to courier a bag for a friend/boyfriend & 11 \\
\hline Travelled to purchase goods for business & 11 \\
\hline Clothing & 3 \\
\hline Hair salon equipment & 2 \\
\hline$N / C$ & 2 \\
\hline Accessories & 1 \\
\hline Camera & 1 \\
\hline Gold & 1 \\
\hline Jewellery & 1 \\
\hline $\mathrm{N} / \mathrm{C}$ & 10 \\
\hline Travelled to meet boyfriend & 8 \\
\hline Recruited for a job & 8 \\
\hline Domestic worker & 3 \\
\hline Masseuse & 2 \\
\hline Domestic worker or factory worker & 1 \\
\hline $\mathrm{N} / \mathrm{C}$ & 1 \\
\hline Rubber tapper & 1 \\
\hline Offered a free holiday & 7 \\
\hline Travelled to seek employment & 6 \\
\hline Travelled for holiday & 4 \\
\hline Travelled to escape an abusive partner & 1 \\
\hline Travelled to visit relatives for financial advice & 1 \\
\hline Travelled to visit a friend & 1 \\
\hline TOTAL & 146 \\
\hline
\end{tabular}


By extension, an international drug run can be conceived of as a 'quick fix' rather than as a sustained profession, or stable source of income. In fact, as a Malaysian journalist recounted to me, drug syndicates tend to recruit couriers via social media in a similar fashion to recruiters of contract workers in the licit economy: 'they tell you it is some form of dispatch work, and they will advertise the amount they will pay you right at the beginning'. This may appeal to precarious workers who are hoping to top-up their earnings. For example, one lawyer told me that his client was working as a masseuse, but became involved in drug couriering for money because she 'wanted more'. Moreover, I found from other interviews and from reviewing the 'defence' information in court documents, that often the payment for carrying a bag (whether or not they knew drugs were inside) was required for an immediate economic need. As stated by one international NGO worker, 'it's not a career as such; it's just to fill a present need' or to 'get you on your feet again'. In many cases these economic factors were gendered. So, several of my participants cited cases involving single mothers, divorcees or pregnant women in need of money to take care of 'family problems', some examples from interviews with lawyers include:

One of the women took part in order to pay for her mother and father's medical bills. She was working at a hair salon, and someone saw her looking sad, and they asked her, 'why?'. She said that she was worried about her parent's medical bills, and she needed to find more work to get more money. So, they suggested that she go and collect a bag abroad for money.

The main reason she travelled was because this guy promised to find a job for her. She knew that she had a little child to support, she was a single mother, and her own mother was old. She was a student at a national university, so it's not like she was just trying to find an easy way out [through drug trafficking]; I think she was just desperate to get a job to support her family.

In another case, a lawyer told me that the woman was in the business of selling electronics with her husband, when they amounted a significant level of debt. They were threatened by their debtors, and told that she must smuggle drugs in order to repay their debt. This fits with other studies' findings that women do smuggle drugs under duress, and oftentimes a family member may be threatened (Huling 1995, 1996; Office of the Sentencing Council 2011; Bailey 2013; Fleetwood 2014).

However, male drug couriers are also known to smuggle drugs for economic reasons (Fleetwood 2014, pp. 113-15). So, what is distinct about these women's cases? The answer lies in the fact that we cannot disentangle the position of female drug couriers from the broader socio-economic landscape of patriarchal society. This is especially the case in the global south. A recent UNICEF report found that girls and women in East and Southeast Asia (where many of the women who were sentenced to death in Malaysia are from) are more likely than their male counterparts to be 'not in employment, education or training' (NEET), this situation worst in the Philippines, Myanmar, Indonesia and Thailand where there is more than a $10 \%$ employment differential between genders (United Nations Children's Fund 2019, p. 82). Moreover, as one consular official astutely pointed out to me, 'women are not necessarily targeted by drug syndicates, but due to the gaps in social welfare women are more likely to be reached by them'. This echoes Richie's (1996) concept of 'gender entrapment', whereby 'some women are forced or coerced into crime by their culturally expected gender roles, the violence in their intimate relationships, and their social position in broader society' (p. 133).

Clearly, we cannot think about the concept of economic precarity in isolation from global structural factors. The lawyers interviewed acknowledged that many of the women they represent are from developing countries in the global south. Indeed, this fact is illustrated by Table 4, which shows that the highest frequencies of nationalities of women sentenced to death for drug trafficking in Malaysia are: Thailand, China, Indonesia, Iran and the Philippines. My interview with a consular official from a developing nation in the global south particularly illuminated this topic. He explained to me that there are a significant number of female nationals from his country who are incarcerated in Malaysia- 
due to drug trafficking (but also human trafficking and sex work) - and he believes this is caused by the high rates of unemployment in his home country. He said: 'because of the lack of jobs back home, most of the youth are frustrated and looking for work. If someone told them, "I want to take you outside the country for some kind of business", they would not hesitate to accept, because there is nothing to do at home'. Similarly, an international NGO worker discussed with me how drug syndicates may target people in developing nations where 'chronic unemployment and chronic wealth inequality make it the perfect grooming ground'.

Table 4. Nationalities of women sentenced to death for drug trafficking in Malaysia 1985-2019 (N/C denotes 'not clear').

\begin{tabular}{cc}
\hline Nationality & Frequency \\
\hline Australia & 1 \\
Cambodia & 3 \\
China & 15 \\
Hong Kong & 1 \\
India & 5 \\
Indonesia & 14 \\
Iran & 14 \\
Japan & 1 \\
Kenya & 2 \\
Malaysia & 12 \\
Mongolia & 2 \\
N/C & 15 \\
New Zealand & 1 \\
Nigeria & 6 \\
Philippines & 12 \\
Republic of Guinea & 4 \\
Singapore & 1 \\
South Africa & 1 \\
Thailand & 24 \\
Togo & 1 \\
Uganda & 1 \\
Uzbekistan & 2 \\
Vietnam & 6 \\
Zambia & 2 \\
TOTAL & $\mathbf{1 4 6}$ \\
\hline
\end{tabular}

There are a large number of women who have been sentenced to death in Malaysia who are from less affluent neighbouring countries such as Indonesia, Thailand and the Philippines. Tables 2 and 3 above, show the number of domestic workers who have been sentenced to death (7) as well as the number of women who travelled to seek employment (6) or because they were recruited for a job (8). Commentators illustrate that there is a transnational flow of labour in the region, particularly female domestic workers, who, as we saw earlier, amount to roughly 300,000-400,000 of the Malaysian population (Harkins 2016; Miles et al. 2019). However, this transnational workforce is incredibly vulnerable: for some, this is their first experience of waged work, making them even more susceptible to exploitation, and indeed, to human trafficking through unscrupulous recruiters (Rosewarne 2014, p. 138). Others have suggested that domestic workers are a particularly attractive proposition for drug syndicates, due to their possession of passports and economic need making them willing and able to travel for money (Cornell Center on the Death Penalty Worldwide 2018, p. 12). We see this in some of the stories of the women on death row in Malaysia, who travelled in search of employment. One lawyer recounted the following information to me about his client:

She worked in a factory, and she was divorced with two children. She was given a work opportunity to come to Malaysia to work as a masseuse. She had never 
travelled before. She didn't even own a suitcase; she turned up at the place where she would collect a ticket with just plastic carrier bags with clothes in them. The person who offered her a job as the masseuse gave her a bag to take with her to Malaysia, and once she arrived in Malaysia she was supposed to drop that bag off at a particular address to a particular person. She had all of this information in a text message. So, she accepted the bag, put her clothes into it, and travelled to Malaysia. When she arrived, the x-ray showed something suspicious in the bag, and drugs were found in the lining.

There have been calls to investigate the nexus between human trafficking and drug trafficking, particularly as it pertains to women who have been sentenced to death for drug trafficking in Southeast Asia (Gerry QC et al. 2018). Here it is argued that human trafficking protections should be afforded to people who have been coerced or deceived into trafficking drugs, particularly 'where there is credible evidence that a person has been trafficked in order to commit criminal offences on behalf of those who make criminal profit', as 'those who are coerced or tricked into an activity such as carrying drugs are not in a position to exercise their free will and so criminal liability cannot be attached to them' (Gerry QC et al. 2018, p. 167). We see in Table 3 above that the most commonly cited reason for travel was 'paid to courier items' (51). Many alleged that they did not realise they were carrying drugs, and instead believed they were couriering other commodities, ranging from clothing (most commonly) to diamonds. This suggests that the human trafficking victim argument could be applied to many of the cases of women who have been sentenced to death in Malaysia. And indeed, I heard stories of women who had been sent on long-winded journeys from their homes in Southeast Asia to Latin America, and back via the African continent or the Middle East. The details of their journeys were changed at the last minute, and tickets were booked for them by their handler. In other cases, women were forced, under duress, to swallow capsules of drugs which they were told contained illegal medicine. The question of the women's agency in this situation is a complex one that other authors researching women and drug trafficking have attempted to address (Fleetwood 2014). However, I am unable to comment on this current situation without having spoken to any of the women on death row first-hand. Notwithstanding, it is important to note that this argument that female drug mules should benefit from human trafficking protections sits uncomfortably with more sociological feminist analyses of anti-human trafficking legislation, which find that these protocols often lead to increased surveillance and criminalisation of women at the border (Pickering and Ham 2014).

If we turn our attention to Tables 5 and 6 below, we see that the most common scenario in which women were arrested was at the airport carrying methamphetamine. This is in keeping with a trend we have seen in the region, starting in the 1990s with a rise in the trafficking of amphetamine-type stimulants (Martel 2013). More recent reports state that there has been a nine-fold increase in the number of methamphetamine tablets seized between the years 2008 and 2015 in East and Southeast Asia (Stoicescu and Lasco 2019 , p. 5). Significantly, there has been a recognition that women in the region are especially vulnerable to being recruited by transnational drug syndicates, and by way of example, the Philippine Drug Enforcement Agency has specifically acknowledged this in its counter-trafficking policy initiatives (Martel 2013). Romantic relationships play a role here. My research findings and others' show that female drug mules are more likely to become involved in drug trafficking through a romantic partner than male drug couriers (Fleetwood 2014, p. 108). And indeed, I heard evidence from my interviews that drug syndicates operating in the Southeast Asian region may use romantic deception as a way to recruit couriers. Furthermore, romantic and economic motivations for drug smuggling are not mutually exclusive. A lawyer told me about one of her female clients on death row, who became unwittingly involved in drug trafficking when she travelled to Malaysia to meet with her online boyfriend, who she trusted as he had promised to secure her a job upon arrival, and said he would 'marry her and take care of her family'. Again, research 
has shown that women are more susceptible to fall for online romance scams than men (Whitty 2018, p. 2).

Table 5. Drug types that women were sentenced to death for trafficking (N/C denotes 'not clear').

\begin{tabular}{cc}
\hline Drug Type & Frequency \\
\hline Methamphetamine & 82 \\
Cannabis & 21 \\
Cocaine & 14 \\
Heroin & 11 \\
Ketamine & 8 \\
and monoacetylmorphine & 3 \\
Heroin, monoacetylmorphine, & 2 \\
methamphetamine and nimetazepam & 1 \\
Heroin, monoacetylmorphine and & 1 \\
methamphetamine & 1 \\
Heroin, monoacetylmorphine and opium & 1 \\
Nimetazepam, ketamine and & 1 \\
methylenedioxymethamphethamine & $\mathbf{1 4 6}$ \\
Morphine & \\
N/C & \\
TOTAL &
\end{tabular}

Table 6. Location of arrest leading to women's death sentence (N/C denotes 'not clear').

\begin{tabular}{cc}
\hline Location of Arrest & Frequency \\
\hline Airport & 91 \\
Bus terminal & 13 \\
Private residency & 10 \\
Hotel & 10 \\
Border checkpoint & 8 \\
Roadside & 6 \\
Car & 5 \\
Carpark & 1 \\
Motorbike & 1 \\
N/C & 1 \\
TOTAL & $\mathbf{1 4 6}$ \\
\hline
\end{tabular}

It goes without saying that these female drug couriers are unlikely to be major profiteers from the drug trafficking business. According to sources, some of the women on death row in Malaysia had been paid approximately USD 500 for their couriering services; a fraction of the worth of the drugs they were carrying (Amnesty International 2019, p. 21). This is because - as my research findings have shown - the women are usually ignorant of what they are actually carrying and thus its worth. Indeed, they could aptly be described as the 'drug working class' within the wider drug trafficking network (Singer et al. 2013). And so, overall, the women's situation of precarity is perpetuated—not solved-by drug trafficking.

\section{Conclusions}

Through an exploration of the drivers behind the disproportionately high rate of foreign national women on death row for drug trafficking in Malaysia, this paper has aimed to illustrate that existing criminological theories of women, crime and economic factors are in need of revision. Previous theorising on the matter has responded to historical economic restructuring, such as neoliberal reforms and the reduction in the welfare state in the latter part of the 20th century, leading to the 'feminisation of poverty' thesis. Instead, I align myself with the work of economists such as Standing (2011) who write about the precaritisation of global labour markets. As we have seen throughout this paper, precarity 
is a gendered phenomenon, and unduly affects women in the global south (Standing 1989). As I found from my 'elite' interviews, as well as analysis of data arising from legal and media database searches, a common theme that runs throughout all accounts of the experiences of women sentenced to death for drug trafficking in Malaysia, is a situation of economic insecurity that has led to participation in the drug trade (knowingly or unknowingly). However, I wish to emphasise that it was usually not a situation of abject poverty, and so I move beyond the paternalist stereotypes of the 'third world woman victim' (Kapur 2002). Crucially, this change in perspective is necessary for addressing judicial attitudes towards female drug mules. I have found that judges in these cases appear to have a preconceived stereotype of the impoverished and uneducated woman who is duped into couriering drugs, which seems to work against the many women who do not fall into this category. In fact, economic insecurity seems to be a greater driver than abject poverty. But the effects of economic precarity may be more difficult for judges to recognise than traditional notions of economic deprivation. Overall, my findings are an indictment of the reality of the current labour market configurations in developing and emerging economies. The majority of women who have been sentenced to death for drug trafficking in Malaysia are from developing countries in the global south and many of the women were unemployed, or working in low-level, low-paid and informal work. From reviewing their cases, we find that the majority of women had travelled across international borders (usually by plane, but sometimes by bus) and were paid to courier an item (many claimed they did not know it was drugs they were carrying). The one-off payment they received was a form of 'quick money' and usually a 'quick fix' for an immediate financial need. Therefore, I take Davies' (2003b) call for feminist criminologists to consider the relationship between women, crime and work as my departure, and conceptualise an international drug run as an extension of women's 'precarious work'. What does this mean for the death penalty for drug trafficking in Malaysia? As my analysis has shown, clearly this death row population is not the 'worst of the worst', in fact, as one of my interviewees stated, it consists of 'everyday people in the gig economy'. Therefore, I hope that this paper may contribute towards the growing body of evidence that suggests that the death sentence for drug offences is grossly disproportionate and ineffectual, and needs to be abolished globally (Sander et al. 2020). Given the relationship between drug trafficking and economic insecurity, I encourage a paradigm shift from criminal justice to social justice.

Funding: This research is funded by a doctoral studentship awarded by the Economic and Social Research Council, UK (award reference: 2094165), and the Gregory Kulkes Scholarship in Law at Balliol College, University of Oxford.

Institutional Review Board Statement: The study was conducted according to the guidelines of the Declaration of Helsinki, and approved by the Social Sciences Ethics Committee of the University of Oxford (R64637/RE001 on 24 September 2019).

Informed Consent Statement: Informed consent was obtained from all subjects involved in the study.

Data Availability Statement: Not applicable.

Conflicts of Interest: The author declares no conflict of interest.

\section{Appendix A}

Table A1. Search terms used for legal databases.

\begin{tabular}{c}
\hline Search Terms \\
\hline "Death penalty" \\
"Capital punishment" \\
"Death sentence" \\
"Dangerous Drugs Act" \\
"Drug trafficking" \\
\hline
\end{tabular}


Table A2. Search terms used for Factiva.

\begin{tabular}{c}
\hline Search Terms \\
\hline "wom?n AND drug* AND Malaysia AND death" \\
"wom?n AND drug* AND Malaysia AND gallows" \\
"wom?n AND drug* AND Malaysia AND hang*" \\
"wom?n AND Malaysia AND drug* AND arrest" \\
"wom?n AND Malaysia AND drug* AND charge" \\
\hline
\end{tabular}

Table A3. Search terms used for Nexis UK.

\section{Search Terms}

"HLEAD (wom*n AND drug! AND Malaysia AND arrest! OR charg!)" "HLEAD (wom*n AND drug! AND Malaysia AND death OR gallows OR hang!)"

Table A4. Combinations of terms used to search remaining media sources.

\begin{tabular}{c}
\hline Search Terms \\
\hline "Women" \\
"Woman" \\
"Drug trafficking" \\
"Death penalty" \\
"Gallows" \\
"Drugs" \\
"Malaysia" \\
"Arrested" \\
"Charged" \\
\hline
\end{tabular}

Table A5. Overview of cases of women sentenced to death for drug trafficking in Malaysia 1985-2019.

\begin{tabular}{|c|c|c|c|}
\hline & Year of Arrest & Year of Death Sentence & Latest Information on Case \\
\hline Case 1 & 1982 & 1985 & Executed in 1990. \\
\hline Case 2 & 1983 & - & $\begin{array}{c}\text { Acquitted and discharged by } \\
\text { Supreme Court (now Federal Court) } \\
\text { in } 1994 .\end{array}$ \\
\hline Case 3 & 1984 & 1986 & Executed in 1987. \\
\hline Case 4 & 1985 & 1987 & $\begin{array}{l}\text { Supreme Court (now Federal Court) } \\
\text { reduced sentence to life } \\
\text { imprisonment in 1989; received an } \\
\text { official pardon and released in } 1996 .\end{array}$ \\
\hline Case 5 & 1986 & 1991 & $\begin{array}{l}\text { Acquitted and discharged by the } \\
\text { (then Supreme Court, now Federal } \\
\text { Court) on } 11 \text { September } 1991 .\end{array}$ \\
\hline Case 6 & 1987 & 1993 & - \\
\hline Case 7 & 1988 & 1991 & Executed in 1994. \\
\hline Case 8 & 1989 & 1994 & - \\
\hline Case 9 & 1997 & 1998 & $\begin{array}{l}\text { Acquitted and discharged by Court } \\
\text { of Appeal in } 2004 .\end{array}$ \\
\hline Case 10 & 1997 & 1999 & $\begin{array}{l}\text { Court of Appeal dismissed appeal in } \\
2004 .\end{array}$ \\
\hline Case 11 & 2001 & - & $\begin{array}{l}\text { Court of Appeal dismissed appeals } \\
\text { in } 2012 \text { and } 2014 .\end{array}$ \\
\hline
\end{tabular}


Table A5. Cont.

\begin{tabular}{|c|c|c|c|}
\hline & Year of Arrest & Year of Death Sentence & Latest Information on Case \\
\hline Case 12 & 2003 & - & $\begin{array}{l}\text { Court of Appeal dismissed appeal in } \\
2011 .\end{array}$ \\
\hline Case 13 & 2004 & 2009 & - \\
\hline Case 14 & 2005 & 2011 & $\begin{array}{l}\text { Court of Appeal dismissed appeal in } \\
2013 .\end{array}$ \\
\hline Case 15 & 2005 & 2010 & $\begin{array}{c}\text { Received official pardon in } 2015 \text { and } \\
\text { death sentence reduced to life } \\
\text { imprisonment. }\end{array}$ \\
\hline Case 16 & 2005 & 2007 & $\begin{array}{l}\text { Court of Appeal dismissed appeal in } \\
2009 .\end{array}$ \\
\hline Case 17 & 2008 & 2010 & - \\
\hline Case 18 & 2008 & - & $\begin{array}{l}\text { Acquitted and discharged by the } \\
\text { Court of Appeal in } 2015 .\end{array}$ \\
\hline Case 19 & 2008 & - & $\begin{array}{l}\text { Acquitted and discharged by the } \\
\text { Court of Appeal in } 2015 .\end{array}$ \\
\hline Case 20 & 2008 & 2012 & $\begin{array}{l}\text { Court of Appeal dismissed appeal in } \\
2014 .\end{array}$ \\
\hline Case 21 & 2009 & 2011 & $\begin{array}{l}\text { Court of Appeal reduced sentence to } \\
12 \text { years' imprisonment in } 2012 \text {. }\end{array}$ \\
\hline Case 22 & 2009 & 2011 & - \\
\hline Case 23 & 2009 & - & $\begin{array}{l}\text { Court of Appeal reduced sentence to } \\
20 \text { years' imprisonment in } 2012 \text {. }\end{array}$ \\
\hline Case 24 & 2009 & 2010 & $\begin{array}{l}\text { Court of Appeal dismissed appeals } \\
\text { in } 2013 \text { and } 2014 .\end{array}$ \\
\hline Case 25 & 2009 & - & $\begin{array}{l}\text { Acquitted and discharged by the } \\
\text { Court of Appeal in } 2014 .\end{array}$ \\
\hline Case 26 & 2009 & 2010 & $\begin{array}{l}\text { Court of Appeal dismissed appeal in } \\
2013 .\end{array}$ \\
\hline Case 27 & 2009 & - & $\begin{array}{l}\text { Court of Appeal dismissed appeal in } \\
2012 .\end{array}$ \\
\hline Case 28 & 2009 & 2012 & $\begin{array}{l}\text { Court of Appeal dismissed appeal in } \\
2015 .\end{array}$ \\
\hline Case 29 & 2009 & 2012 & $\begin{array}{l}\text { Court of Appeal dismissed appeal in } \\
2015 .\end{array}$ \\
\hline Case 30 & 2009 & 2012 & $\begin{array}{l}\text { Acquitted and discharged by the } \\
\text { Court of Appeal in } 2015 .\end{array}$ \\
\hline Case 31 & 2009 & 2012 & $\begin{array}{l}\text { Court of Appeal dismissed appeal in } \\
2014 .\end{array}$ \\
\hline Case 32 & 2009 & - & $\begin{array}{l}\text { Court of Appeal dismissed appeal in } \\
2015 .\end{array}$ \\
\hline Case 33 & 2009 & 2012 & - \\
\hline Case 34 & 2009 & - & $\begin{array}{l}\text { Court of Appeal dismissed appeal in } \\
2015 .\end{array}$ \\
\hline Case 35 & 2009 & 2011 & $\begin{array}{l}\text { Court of Appeal dismissed appeal in } \\
2014 .\end{array}$ \\
\hline Case 36 & 2009 & - & $\begin{array}{l}\text { Acquitted and discharged by the } \\
\text { Court of Appeal in } 2013 .\end{array}$ \\
\hline
\end{tabular}


Table A5. Cont.

\begin{tabular}{|c|c|c|c|}
\hline & Year of Arrest & Year of Death Sentence & Latest Information on Case \\
\hline Case 37 & 2010 & - & $\begin{array}{l}\text { Court of Appeal dismissed appeal in } \\
2013 .\end{array}$ \\
\hline Case 38 & 2010 & - & $\begin{array}{l}\text { Court of Appeal dismissed appeal in } \\
2017 .\end{array}$ \\
\hline Case 39 & 2010 & 2012 & - \\
\hline Case 40 & 2010 & 2011 & - \\
\hline Case 41 & 2010 & 2013 & $\begin{array}{l}\text { Court of Appeal dismissed appeal in } \\
2015 .\end{array}$ \\
\hline Case 42 & 2010 & 2013 & $\begin{array}{l}\text { Court of Appeal dismissed appeal in } \\
2015 .\end{array}$ \\
\hline Case 43 & 2010 & 2011 & $\begin{array}{l}\text { Court of Appeal dismissed appeal in } \\
2015 .\end{array}$ \\
\hline Case 44 & 2010 & 2011 & $\begin{array}{l}\text { Court of Appeal dismissed appeal in } \\
2013 .\end{array}$ \\
\hline Case 45 & 2010 & 2012 & $\begin{array}{l}\text { Court of Appeal dismissed appeal in } \\
2014 .\end{array}$ \\
\hline Case 46 & 2010 & - & $\begin{array}{l}\text { Court of Appeal dismissed appeal in } \\
2014 .\end{array}$ \\
\hline Case 47 & 2010 & 2012 & $\begin{array}{l}\text { Court of Appeal dismissed appeal in } \\
2013 .\end{array}$ \\
\hline Case 48 & 2010 & 2012 & $\begin{array}{l}\text { Court of Appeal dismissed appeal in } \\
2015 .\end{array}$ \\
\hline Case 49 & 2010 & 2016 & - \\
\hline Case 50 & 2010 & 2012 & $\begin{array}{l}\text { Acquitted and discharged by the } \\
\text { Court of Appeal in } 2013 .\end{array}$ \\
\hline Case 51 & 2010 & 2011 & $\begin{array}{l}\text { Court of Appeal dismissed appeal in } \\
2013 .\end{array}$ \\
\hline Case 52 & 2010 & 2013 & $\begin{array}{l}\text { Court of Appeal dismissed appeal in } \\
2015 .\end{array}$ \\
\hline Case 53 & 2010 & 2013 & $\begin{array}{l}\text { Court of Appeal dismissed appeal in } \\
2015 .\end{array}$ \\
\hline Case 54 & 2010 & 2013 & $\begin{array}{c}\text { Court of Appeal sent case back to } \\
\text { High Court for retrial in } 2016 .\end{array}$ \\
\hline Case 55 & 2011 & 2015 & $\begin{array}{l}\text { Court of Appeal overruled High } \\
\text { Court's reduction in sentence and } \\
\text { imposed a death sentence in } 2015 \text {. }\end{array}$ \\
\hline Case 56 & 2011 & 2012 & $\begin{array}{l}\text { Court of Appeal dismissed appeal in } \\
2014 .\end{array}$ \\
\hline Case 57 & 2011 & - & $\begin{array}{l}\text { Court of Appeal dismissed appeal in } \\
2015 .\end{array}$ \\
\hline Case 58 & 2011 & 2015 & $\begin{array}{l}\text { Court of Appeal reduced sentence to } \\
18 \text { years' imprisonment in } 2016 .\end{array}$ \\
\hline Case 59 & 2011 & - & $\begin{array}{l}\text { Court of Appeal dismissed appeal in } \\
2014 .\end{array}$ \\
\hline Case 60 & 2011 & 2014 & $\begin{array}{l}\text { Court of Appeal dismissed appeal in } \\
2016 .\end{array}$ \\
\hline Case 61 & 2011 & 2012 & - \\
\hline
\end{tabular}


Table A5. Cont.

\begin{tabular}{|c|c|c|c|}
\hline & Year of Arrest & Year of Death Sentence & Latest Information on Case \\
\hline Case 62 & 2011 & 2012 & $\begin{array}{l}\text { Court of Appeal dismissed appeal in } \\
2015 .\end{array}$ \\
\hline Case 63 & 2011 & - & $\begin{array}{l}\text { Court of Appeal dismissed appeal in } \\
2015 .\end{array}$ \\
\hline Case 64 & 2011 & 2012 & - \\
\hline Case 65 & 2011 & - & $\begin{array}{l}\text { Acquitted and discharged by the } \\
\text { Court of Appeal in } 2016 .\end{array}$ \\
\hline Case 66 & 2011 & - & $\begin{array}{l}\text { Court of Appeal dismissed appeal in } \\
2015 .\end{array}$ \\
\hline Case 67 & 2011 & 2013 & $\begin{array}{l}\text { Court of Appeal dismissed appeal in } \\
2015 .\end{array}$ \\
\hline Case 68 & 2011 & - & $\begin{array}{l}\text { Court of Appeal dismissed appeal in } \\
2015 .\end{array}$ \\
\hline Case 69 & 2011 & 2015 & $\begin{array}{l}\text { Court of Appeal allowed appeal and } \\
\text { reduced sentence to } 3 \text { years and } 2 \\
\text { months' imprisonment in } 2017 .\end{array}$ \\
\hline Case 70 & 2011 & 2014 & $\begin{array}{c}\text { Court of Appeal dismissed appeal in } \\
2014 \text { and Federal Court dismissed } \\
\text { appeal in 2017. }\end{array}$ \\
\hline Case 71 & 2011 & - & $\begin{array}{l}\text { Court of Appeal dismissed appeal in } \\
2015 .\end{array}$ \\
\hline Case 72 & 2012 & 2014 & $\begin{array}{l}\text { Court of Appeal dismissed appeal in } \\
2015 .\end{array}$ \\
\hline Case 73 & 2012 & 2013 & - \\
\hline Case 74 & 2012 & 2013 & $\begin{array}{l}\text { Court of Appeal dismissed appeal in } \\
\text { 2015, but the Federal Court held } \\
\text { appeal and sentence was commuted } \\
\text { in } 2016 .\end{array}$ \\
\hline Case 75 & 2012 & 2014 & $\begin{array}{l}\text { Court of Appeal dismissed appeal in } \\
2017 .\end{array}$ \\
\hline Case 76 & 2012 & - & $\begin{array}{l}\text { Court of Appeal dismissed appeal in } \\
2017 .\end{array}$ \\
\hline Case 77 & 2012 & 2013 & $\begin{array}{l}\text { Court of Appeal dismissed appeal in } \\
2015 .\end{array}$ \\
\hline Case 78 & 2012 & 2014 & $\begin{array}{l}\text { Court of Appeal dismissed appeal in } \\
2015 .\end{array}$ \\
\hline Case 79 & 2012 & - & $\begin{array}{l}\text { Court of Appeal dismissed appeal } \\
\text { challenging the acquittal of } \\
\text { co-accused in } 2019 .\end{array}$ \\
\hline Case 80 & 2012 & 2015 & $\begin{array}{l}\text { Court of Appeal dismissed appeals } \\
\text { in } 2018 \text { and } 2019 .\end{array}$ \\
\hline Case 81 & 2012 & - & $\begin{array}{l}\text { Court of Appeal dismissed appeal in } \\
2019 .\end{array}$ \\
\hline Case 82 & 2012 & - & $\begin{array}{l}\text { Court of Appeal dismissed appeal in } \\
2017 .\end{array}$ \\
\hline Case 83 & 2012 & 2015 & - \\
\hline Case 84 & 2012 & 2015 & - \\
\hline
\end{tabular}


Table A5. Cont.

\begin{tabular}{|c|c|c|c|}
\hline & Year of Arrest & Year of Death Sentence & Latest Information on Case \\
\hline Case 85 & 2012 & - & $\begin{array}{l}\text { Court of Appeal dismissed appeal in } \\
\qquad 2015\end{array}$ \\
\hline Case 86 & 2012 & - & $\begin{array}{l}\text { Court of Appeal dismissed appeal in } \\
2016 .\end{array}$ \\
\hline Case 87 & 2012 & 2017 & $\begin{array}{l}\text { Court of Appeal overturned the } \\
\text { High Court's earlier acquittal and } \\
\text { imposed a death sentence in } 2017 \text {. }\end{array}$ \\
\hline Case 88 & 2012 & - & $\begin{array}{l}\text { Court of Appeal dismissed appeal in } \\
2017 .\end{array}$ \\
\hline Case 89 & 2012 & - & $\begin{array}{l}\text { Court of Appeal dismissed appeal in } \\
2019 .\end{array}$ \\
\hline Case 90 & 2013 & - & $\begin{array}{l}\text { Court of Appeal dismissed appeal in } \\
2017 .\end{array}$ \\
\hline Case 91 & 2013 & 2018 & $\begin{array}{l}\text { Court of Appeal overturned the } \\
\text { High Court's acquittal and imposed } \\
\text { a death sentence in } 2018 .\end{array}$ \\
\hline Case 92 & 2013 & 2015 & $\begin{array}{l}\text { Court of Appeal overturned the } \\
\text { High Court's acquittal and } \\
\text { sentenced her to death in } 2015 .\end{array}$ \\
\hline Case 93 & 2013 & 2015 & $\begin{array}{l}\text { Court of Appeal dismissed appeal in } \\
2017 .\end{array}$ \\
\hline Case 94 & 2013 & 2015 & $\begin{array}{l}\text { Court of Appeal dismissed appeal in } \\
2017 .\end{array}$ \\
\hline Case 95 & 2013 & 2015 & $\begin{array}{l}\text { Court of Appeal dismissed appeal in } \\
2016 .\end{array}$ \\
\hline Case 96 & 2013 & - & $\begin{array}{l}\text { Court of Appeal dismissed appeal in } \\
2017 .\end{array}$ \\
\hline Case 97 & 2013 & - & $\begin{array}{l}\text { Acquitted and discharged by the } \\
\text { Court of Appeal in } 2015 .\end{array}$ \\
\hline Case 98 & 2013 & 2015 & $\begin{array}{l}\text { Court of Appeal dismissed appeal in } \\
2018 .\end{array}$ \\
\hline Case 99 & 2013 & 2017 & $\begin{array}{l}\text { Court of Appeal overturned the } \\
\text { High Court's sentence of } 15 \text { years } \\
\text { and imposed death sentence in } 2017 .\end{array}$ \\
\hline Case 100 & 2013 & 2017 & $\begin{array}{l}\text { Court of Appeal dismissed appeal in } \\
2018 .\end{array}$ \\
\hline Case 101 & 2013 & - & $\begin{array}{l}\text { Court of Appeal dismissed appeal in } \\
2018 .\end{array}$ \\
\hline Case 102 & 2013 & - & $\begin{array}{l}\text { Court of Appeal dismissed appeal in } \\
2019 .\end{array}$ \\
\hline Case 103 & 2013 & 2016 & $\begin{array}{l}\text { Court of Appeal dismissed appeal in } \\
2018 .\end{array}$ \\
\hline Case 104 & 2013 & 2015 & $\begin{array}{c}\text { Court of Appeal dismissed appeal in } \\
2017 \text { and Federal Court dismissed } \\
\text { appeal in } 2020 .\end{array}$ \\
\hline Case 105 & 2013 & 2017 & $\begin{array}{l}\text { Court of Appeal dismissed appeal in } \\
2019 .\end{array}$ \\
\hline
\end{tabular}


Table A5. Cont.

\begin{tabular}{|c|c|c|c|}
\hline & Year of Arrest & Year of Death Sentence & Latest Information on Case \\
\hline Case 106 & 2013 & 2016 & $\begin{array}{l}\text { Court of Appeal dismissed appeal in } \\
2017 .\end{array}$ \\
\hline Case 107 & 2013 & - & $\begin{array}{l}\text { Court of Appeal dismissed appeal in } \\
2017 .\end{array}$ \\
\hline Case 108 & 2013 & - & $\begin{array}{l}\text { Court of Appeal dismissed appeal in } \\
2018 .\end{array}$ \\
\hline Case 109 & 2013 & - & $\begin{array}{l}\text { Court of Appeal dismissed appeal in } \\
2016 .\end{array}$ \\
\hline Case 110 & 2013 & 2016 & $\begin{array}{l}\text { Court of Appeal overturned the } \\
\text { High Court's sentence of } 18 \text { years' } \\
\text { imprisonment and imposed death } \\
\text { sentence in } 2016 .\end{array}$ \\
\hline Case 111 & 2013 & 2017 & $\begin{array}{l}\text { Court of Appeal dismissed appeal in } \\
2019 .\end{array}$ \\
\hline Case 112 & 2013 & 2015 & $\begin{array}{l}\text { Court of Appeal dismissed appeal in } \\
2016 .\end{array}$ \\
\hline Case 113 & 2013 & 2016 & $\begin{array}{l}\text { Court of Appeal dismissed appeal in } \\
2017 .\end{array}$ \\
\hline Case 114 & 2013 & 2017 & $\begin{array}{l}\text { Court of Appeal dismissed appeal in } \\
2019 .\end{array}$ \\
\hline Case 115 & 2013 & 2017 & $\begin{array}{l}\text { Court of Appeal dismissed appeal in } \\
2019 .\end{array}$ \\
\hline Case 116 & 2013 & 2016 & $\begin{array}{l}\text { Court of Appeal dismissed appeal in } \\
2018, \text { but the Federal Court accepted } \\
\text { appeal and reduced sentence to } 20 \\
\text { years' imprisonment in } 2019 .\end{array}$ \\
\hline Case 117 & 2013 & 2017 & - \\
\hline Case 118 & 2013 & 2017 & - \\
\hline Case 119 & 2013 & - & $\begin{array}{l}\text { Court of Appeal dismissed appeal in } \\
2019 .\end{array}$ \\
\hline Case 120 & 2014 & 2016 & $\begin{array}{l}\text { Court of Appeal overturned the } \\
\text { High Court's sentence of } 10 \text { years' } \\
\text { imprisonment for possession and } \\
\text { increased the charge to trafficking } \\
\text { and a sentence of death in } 2016 .\end{array}$ \\
\hline Case 121 & 2014 & - & $\begin{array}{l}\text { Court of Appeal dismissed appeal in } \\
2019 .\end{array}$ \\
\hline Case 122 & 2014 & - & $\begin{array}{l}\text { Court of Appeal dismissed appeal in } \\
2019 .\end{array}$ \\
\hline Case 123 & 2014 & - & $\begin{array}{l}\text { Court of Appeal dismissed appeal in } \\
2018 .\end{array}$ \\
\hline Case 124 & 2014 & 2016 & $\begin{array}{l}\text { Court of Appeal dismissed appeal in } \\
2017 .\end{array}$ \\
\hline Case 125 & 2014 & 2016 & - \\
\hline Case 126 & 2014 & 2016 & $\begin{array}{l}\text { Court of Appeal dismissed appeal in } \\
2018 .\end{array}$ \\
\hline Case 127 & 2014 & 2015 & $\begin{array}{l}\text { Court of Appeal dismissed appeal in } \\
2017 .\end{array}$ \\
\hline
\end{tabular}


Table A5. Cont.

\begin{tabular}{|c|c|c|c|}
\hline & Year of Arrest & Year of Death Sentence & Latest Information on Case \\
\hline Case 128 & 2014 & 2016 & - \\
\hline Case 129 & 2014 & 2016 & $\begin{array}{l}\text { Court of Appeal dismissed appeal in } \\
2017 .\end{array}$ \\
\hline Case 130 & 2014 & 2015 & $\begin{array}{l}\text { Court of Appeal dismissed appeal in } \\
2017 .\end{array}$ \\
\hline Case 131 & 2014 & - & $\begin{array}{l}\text { Court of Appeal dismissed appeal in } \\
\text { 2017, but Federal Court quashed } \\
\text { death sentence and reduced charge } \\
\text { to possession in } 2019 .\end{array}$ \\
\hline Case 132 & 2014 & 2016 & - \\
\hline Case 133 & 2014 & 2017 & - \\
\hline Case 134 & 2014 & 2017 & $\begin{array}{l}\text { Court of Appeal dismissed appeal in } \\
2019 .\end{array}$ \\
\hline Case 135 & 2014 & 2016 & - \\
\hline Case 136 & 2014 & 2016 & $\begin{array}{l}\text { Court of Appeal dismissed appeal in } \\
2018 .\end{array}$ \\
\hline Case 137 & 2014 & 2017 & - \\
\hline Case 138 & 2014 & 2018 & $\begin{array}{l}\text { Court of Appeal overturned the } \\
\text { High Court's acquittal in } 2018 \text { and } \\
\text { imposed death sentence, but } \\
\text { acquitted and discharged by the } \\
\text { Federal Court in } 2019 .\end{array}$ \\
\hline Case 139 & 2015 & 2017 & - \\
\hline Case 140 & 2015 & - & $\begin{array}{l}\text { Court of Appeal dismissed appeal in } \\
2019 .\end{array}$ \\
\hline Case 141 & 2015 & 2017 & - \\
\hline Case 142 & 2015 & 2017 & $\begin{array}{l}\text { Acquitted and discharged by High } \\
\text { Court in 2016, but overturned on } \\
\text { appeal and resentenced to death by } \\
\text { High Court in 2017. Court of Appeal } \\
\text { rejected appeal in } 2018 .\end{array}$ \\
\hline Case 143 & 2017 & - & $\begin{array}{l}\text { Court of Appeal dismissed appeal in } \\
2018 .\end{array}$ \\
\hline Case 144 & 2018 & 2019 & - \\
\hline Case 145 & 2018 & 2019 & - \\
\hline Case 146 & - & - & $\begin{array}{l}\text { Court of Appeal dismissed appeal in } \\
2015 .\end{array}$ \\
\hline
\end{tabular}

(- denotes absence of data).

\section{References}

Amnesty International. 2019. Fatally Flawed: Why Malaysia Must Abolish the Death Penalty. London: International Drug Policy Consortium.

Antolak-Saper, Natalia, Sara Kowal, Samira Lindsey, Chow Ying Ngeow, and Thaatchaayini Kananatu. 2020. Drug Offences and the Death Penalty in Malaysia: Fair Trial Rights and Ramifications. Clayton: Victoria.

$\mathrm{Au}$, Wee Chan, Uracha Chatrakul Na Ayudhya, Yan Soon Tan, and Pervaiz K. Ahmed. 2019. The Work-Life Experiences of an Invisible Workforce: The Case of Live-in Women Migrant Domestic Workers in Malaysia. Equality, Diversity and Inclusion: An International Journal 39: 567-83. [CrossRef]

Bailey, Corin. 2013. Exploring Female Motivations for Drug Smuggling on the Island of Barbados: Evidence From Her Majesty's Prison, Barbados. Feminist Criminology 8: 117-41. [CrossRef] 
Belknap, Joanne, and Kristi Holsinger. 2006. The Gendered Nature of Risk Factors for Delinquency. Feminist Criminology 1: 48-71. [CrossRef]

Callamard, Agnes. 2018. Women and Girls on Death Row Require Specific Gender-Based Responses and Policies. United Nations Office of the High Commissioner. Available online: https:/ / www.ohchr.org/EN/NewsEvents/Pages/DisplayNews.aspx?NewsID=23 705\&LangID $=\mathrm{E}$ (accessed on 30 January 2021).

Carlen, Pat. 1988. Women, Crime and Poverty. Milton Keynes: Open University Press.

Carrington, Kerry, Russell Hogg, and Máximo Sozzo. 2016. Southern Criminology. British Journal of Criminology 56: 1-20. [CrossRef]

Carroll, Jenny E. 1996. Images of Women and Capital Sentencing among Female Offenders: Exploring the Outer Limits of the Eighth Amendment and Articulated Theories of Justice. Texas Law Review 75: 1413-54.

Chesney-Lind, Meda. 1997. Female Offender: Girls, Women and Crime. Thousand Oaks: Sage Publications.

Chunn, Dorothy E., and Shelley A. M. Gavigan. 2004. Welfare Law, Welfare Fraud, and the Moral Regulation of the 'Never Deserving' Poor. Social \& Legal Studies 13: 219-43. [CrossRef]

Connell, Raewyn. 2007. Southern Theory. Cambridge: Polity.

Constant, Chloé. 2017. Historical Evolution and Global Changes in Women's Imprisonment in Peru. The Howard Journal of Criminal Justice 56: 326-42. [CrossRef]

Cornell Center on the Death Penalty Worldwide. 2018. Judged for More Than Her Crime: A Global Overview of Women Facing the Death Penalty. Ithaca: Cornell Law School.

Corston, Jean Ann. 2007. The Corston Report: A Review of Women with Particular Vulnerabilities in the Criminal Justice System. Probation Journal 54: 285-87. [CrossRef]

Creswell, John W. 2007. Qualitative Inquiry and Research Design: Choosing among Five Approaches. Thousand Oaks: Sage Publications, Inc.

Daly, Kathleen. 1989. Gender and Varieties of White-Collar Crime. Criminology 27: 769-94. [CrossRef]

Daly, Kathleen. 1992. Women's Pathways to Felony Court: Feminist Theories of Lawbreaking and Problems of Representation. Southern California Review of Law and Women's Studies 2: 11-52.

Davies, Pamela. 2003a. Is Economic Crime a Man's Game? Feminist Theory 4: 282-303. [CrossRef]

Davies, Pamela. 2003b. Women, Crime and Work: Gender and the Labour Market. The Centre for Crime and Justice Studies 53: 18-19. [CrossRef]

Davis, Martha F. 1991. War on Poverty, War on Women. New York Times.

Elias, Juanita. 2006. The Gendered Political Economy of Control and Resistance on the Shop Floor of the Multinational Firm: A Case-Study from Malaysia. New Political Economy 10: 203-22. [CrossRef]

Elson, Diane, and Ruth Pearson. 1981. 'Nimble Fingers Make Cheap Workers': An Analysis of Women's Employment in Third World Export Manufacturing. Feminist Review 7: 87-107. [CrossRef]

Esmee Fairbairn Foundation. 2003. A Bitter Pill to Swallow: The Sentencing of Foreign National Drug Couriers. London: Re-thinking Crime and Justice.

Fleetwood, Jennifer. 2014. Drug Mules: Women in the International Cocaine Trade. Basingstoke: Palgrave Macmillan.

Fleetwood, Jennifer, and Lizzie Seal. 2017. Women, drugs and the death penalty: Framing sandiford. The Howard Journal of Crime and Justice 56: 358-81. [CrossRef]

Franck, Anja K. 2016. From Formal Employment to Street Vending: Malaysian Women's Labour Force Participation over the Life Course. In The Everyday Political Economy of Southeast Asia. Edited by Juanita Elias and Lena Rethel. Cambridge: Cambridge University Press.

Fudge, Judy, and Rosemary Owens. 2006. Precarious Work, Women and the New Economy: The Challenge to Legal Norms. Oxford: Hart Publishing.

Gelsthorpe, Loraine. 2010. Women, Crime and Control. Criminology E Criminal Justice 10: 375-86. [CrossRef]

Gerry QC, Felicity, Thomas Harré, Nathalina Naibaho, and Julia Muraszkiewicz. 2018. Is the Law an Ass When It Comes to Mules? How Indonesia Can Lead a New Global Approach to Treating Drug Traffickers as Human Trafficked Victims. Asian Journal of International Law 8: 166-88. [CrossRef]

Green, Penny. 1996. Drug Couriers: The Construction of a Public Enemy. In Drug Couriers: A New Perspective. Edited by p. Green. London: Quartet Books.

Han, Clara. 2018. Precarity, Precariousness, and Vulnerability. Annual Review of Anthropology 47: 331-43. [CrossRef]

Han, Lim Chee, Chow Ying Ngeow, and Harchanadevi Arivananthan. 2018. High Incidence of Judicial Errors in Capital Punishment Cases in Malaysi. Penang: Penang Institute.

Harkins, Benjamin. 2016. Review of Labour Migration Policy in Malaysia. Bangkok: ILO.

Harring, Sidney. 1991. Death, Drugs and Development: Malaysia's Mandatory Death Penalty for Traffickers and the International War on Drugs. Columbia Journal of Transnational Law 29: 365-401.

Heaven, Olga. 1996. Hibiscus: Working with Nigerian Women Prisoners. In Drug Couriers: A New Perspective. London: Quartet Books.

Hood, Roger. 2013. The Death Penalty in Malaysia: Public Opinion on the Mandatory Death Penalty for Drug Trafficking, Murder and Firearms Offences. London: The Death Penalty Project.

Hood, Roger, and Carolyn Hoyle. 2015. The Death Penalty: A Worldwide Perspective. Oxford: Oxford University Press.

Hoyle, Carolyn. 2019. Capital Punishment at the Intersections of Discrimination and Disadvantage: The Plight of Foreign Nationals. In Comparative Capital Punishment. Edited by Carol S. Steiker and Jordan M. Steiker. Northampton: Edward Elgar Publishing. 
Huling, Tracy. 1995. Women Drug Couriers-Sentencing Reform Needed for Prisoners of War. Criminal Justice 9: 15-62.

Huling, Tracy. 1996. Prisoners of War: Women Drug Couriers in the United States. In Drug Couriers: A New Perspective. London: Quartet Books.

Jeffries, Samantha, and Chontit Chuenurah. 2019. Vulnerabilities, Victimisation, Romance and Indulgence: Thai Women's Pathways to Prison in Cambodia for International Cross Border Drug Trafficking. International Journal of Law, Crime and Justice 56: 39-52. [CrossRef]

Johnson, David T., and Franklin E. Zimring. 2006. Taking Capital Punishment Seriously. Asian Journal of Criminology 1: 89-95. [CrossRef]

Kapur, Ratna. 2002. The Tragedy of Victimization Rhetoric: Resurrecting the Native Subject in International/Postcolonial Feminist Legal Politics. Harvard Human Rights Law Journal 15: 1-37.

Kaur, Amarjit. 2000. Working on the Global Conveyor Belt: Women Workers in Industrialising Malaysia. Asian Studies Review 24: 213-30. [CrossRef]

Klein, Dorie. 1973. The Etiology of Female Crime: A Review of the Literature. Issues in Criminology 8: 3-30.

Kumar, Dileep M., Noor Azizi Ismail, and Normala S. Govindarajo. 2014. Way to Measure the Concept Precarious Working Conditions in Oil Plantations. Asian Social Science 10: 1-10. [CrossRef]

Lim, Lin Lean. 1993. The Feminization of Labour in the Asia-Pacific Rim Countries: From Contributing to Economic Dynamism to Bearing the Brunt of Structural Adjustments. In Human Resources in Development along the Asia-Pacific Rim. Edited by Naohiro Ogawa, Gavin W. Jones and Jeffrey G. Williamson. Oxford, New York and Singapore: Oxford University Press.

Maher, Lisa. 1997. Sexed Work: Gender, Race, and Resistance in a Brooklyn Drug Market. Oxford: Clarendon Press.

Martel, Stéphanie. 2013. The Recruitment of Female 'Mules' by Transnational Criminal Organizations: Securitization of Drug Trafficking in the Philippines and Beyond. Social Transformations 1: 13-41. [CrossRef]

Mazlan, Nurul Hazrina Mazlan, and Affizal Ahmad. 2012. Psychological Profile of Malaysian Female Prisoners. Global Advanced Research Journal of Educational Research and Review 1: 106-11.

McCorkel, Jill. 2004. Criminally Dependent? Gender, Punishment, and the Rhetoric of Welfare Reform. Social Politics 11: 386-410. [CrossRef]

Miles, Lilian, Suzan Lewis, Lai Wan Teng, and Suziana Mat Yasin. 2019. Advocacy for Women Migrant Workers in Malaysia through an Intersectionality Lens. Journal of Industrial Relations 61: 682-703. [CrossRef]

Miller, Jody. 1998. Up It up: Gender and the Accomplishment of Street Robbery. Criminology 36: 37-66. [CrossRef]

Neilson, Brett, and Ned Rossiter. 2008. Precarity as a Political Concept, or, Fordism as Exception. Theory, Culture and Society 25: 51-72. [CrossRef]

Office of the Sentencing Council. 2011. Drug 'Mules': Twelve Case Studies. London: Office of the Sentencing Council.

Olmo, Rosa Del. 1986. Female Criminality and Drug Trafficking. In Drugs in Latin America. Edited by E. Morales. Williamsburg: College of William and Mary, Dept. of Anthropology.

Ong, Aihwa. 1987. Spirits of Resistance and Capitalist Discipline: Factory Women in Malaysia. Albany: State University of New York Press.

Pascoe, Daniel. 2016. Researching the Death Penalty in Closed or Partially-Closed Criminal Justice Systems. In Changing Contours of Criminal Justice. Edited by Mary Bosworth, Carolyn Hoyle and Lucia Zedner. Oxford: University of Oxford Press.

Pascoe, Daniel. 2019. Last Chance for Life: Clemency in Southeast Asian Death Penalty Cases. Oxford: Oxford University Press.

Pearce, Diana. 1978. The Feminization of Poverty: Women, Work, and Welfare. Urban and Social Change Review 11: $28-36$.

Phoenix, Joanna. 1999. Making Sense of Prostitution. Basingstoke: Macmillan Press.

Pickering, Sharon, and Julie Ham. 2014. Hot Pants at the Border: Sorting Sex Work from Trafficking. The British Journal of Criminology 54: 2-19. [CrossRef]

Potter, Hillary. 2015. Intersectionality and Criminology: Disrupting and Revolutionizing Studies of Crime. London: Taylor and Francis.

Pye, Oliver, Ramlah Daud, Yuyun Harmono, and Tatat. 2012. Precarious Lives: Transnational Biographies of Migrant Oil Palm Workers. Asia Pacific Viewpoint 53: 330-42. [CrossRef]

Richie, Beth. 1996. Compelled to Crime: The Gender Entrapment of Battered Black Women. New York and London: Routledge.

Rosewarne, Stuart. 2014. Migrant Domestic Work: From Precarious to Precarisation. Journal Für Entwicklungspolitik 3: 133-54. [CrossRef]

Samuel, Rachel, and Roaimah Omar. 2012. Female Prisoners in Malaysia: An Examination of Socio-Demographic Characteristics. Procedia-Social and Behavioral Sciences 65: 505-10. [CrossRef]

Sander, Gen, Giada Girelli, and Adrià Cots Fernández. 2020. The Death Penalty for Drug Offences: Global Overview 2019. London: Harm Reduction International.

Shapiro, Andrea. 2000. Unequal Before the Law: Men, Women and the Death Penalty. The American University Journal of Gender, Social Policy and the Law 8: 427-70.

Shatz, Steven F., and Naomi R. Shatz. 2012. Chivalry Is Not Dead: Murder, Gender, and the Death Penalty. Berkeley Journal of Gender, Law and Justice 27: 64-112.

Singer, Merrill, William Tootle, and Joy Messerschmidt. 2013. Living in an Illegal Economy: The Small Lives That Create Big Bucks in the Global Drug Trade. SAIS Review of International Affairs 33: 123-35. [CrossRef]

Standing, Guy. 1989. Global Feminization through Flexible Labor. World Development 17: 1077-95. [CrossRef]

Standing, Guy. 2011. The Precariat: The New Dangerous Class. London; New York: Bloomsbury Academic. 
Stoicescu, Claudia, and Gideon Lasco. 2019. 10 Years of Drug Policy in Asia: How Far Have We Come? A Civil Society Shadow Report. London: International Drug Policy Consortium.

Streib, Victor L. 1990. Death Penalty for Female Offenders. University of Cincinnati Law Review 58: 845-80.

Streib, Victor L. 1992. Death Penalty for Battered Women. Florida State University Law Review 20: 163-94.

Streib, Victor L. 2002. Gendering the Death Penalty: Countering Sex Bias in a Masculine Sanctuary. Ohio State Law Journal 63: 433-74.

Streib, Victor L. 2005. Rare and Inconsistent: The Death Penalty for Women. Fordham Urb. LJ 33: 101-35.

Streib, Victor L. 2006. The Fairer Death: Executing Women in Ohio. Athens: Ohio University Press.

Sudbury, Julia. 2005. Mules, Yardies and Other Folk Devils: Mapping Cross Border Imprisonment in Britain. In Global Lockdown: Race, Gender, and the Prison-Industrial Complex. Edited by J. C. Oparah. London and New York: Routledge.

Teh, Yik Koon. 2006. Female Prisoners in Malaysia. Journal of Offender Rehabilitation 43: 45-64. [CrossRef]

Torres, Andreina. 2008. Drogas, Cárcel y Género En Ecuador: La Experiencia de Mujeres Mulas. Quito: FLASCO/Abya Yala.

United Nations Children's Fund. 2019. Gender Counts: A Quantitative Assessment of Gender Inequality and Its Impact on Girls and Boys in East and Southeast Asia and the Pacific. Bangkok: ILO.

Wacquant, Loïc. 1999. Prisons of Poverty. Minneapolis: University of Minnesota Press.

Whitty, Monica T. 2018. Do You Love Me? Psychological Characteristics of Romance Scam Victims. Cyberpsychology, Behavior, and Social Networking 21: 105-9. [CrossRef]

World Prison Brief. 2019. Malaysia. Available online: https://www.prisonstudies.org/country/malaysia (accessed on 2 December 2020).

Zamzam, Ruzanna, and S. Mohamed Hatta. 2000. Specific Psychiatric Disorders Among Convicted Female Offenders in a Malaysian Prison. Malaysian Journal of Psychiatry 8: 34-42. 